\title{
Relationship between C-reactive protein and other cardiovascular risk factors in hypercholesterolemic individuals $^{\mathbf{a}}$
}

\section{Relação entre a proteína C reativa e os fatores de risco para doenças cardiovasculares em indivíduos hipercolesterolêmicos}

\section{ABSTRACT}

Objective: To evaluate the correlation between ultrasensitive $\mathrm{C}$-reactive protein (us-CRP) and markers of cardiovascular risk in hypercholesterolemic adults of differing nutritional status. Methods: Forty-six hypercholesterolemic subjects ( 7 men: 30 to 70 years; 39 women: 45 to 70 years) with total cholesterol $>240 \mathrm{mg} / \mathrm{dL}$ were studied. Anthropometric variables (weight, height, and waist and hip circumference) were measured, as well as us-CRP, total cholesterol (TC), HDL-C, LDL-C, VLDL-C, triglycerides, apolipoprotein AI, apolipoprotein B, glucose and fasting insulin, and homeostasis model assessment (HOMA-IR) of insulin resistance. Spearman correlations and multiple linear regression analysis were performed at a level of significance of $5 \%$. Results: Plasma levels of triglycerides, VLDL-C, glucose, HDL-C and us-CRP were higher in overweight subjects $(p<0.05)$. Ultrasensitive CRP was positively correlated with body mass index $(\mathrm{r}=0.32)$ and hip circumference $(\mathrm{r}=0.30)$, as well as with TC $(\mathrm{r}=0.33)$, apolipoprotein $\mathrm{B}(\mathrm{r}=0.36)$ and glucose $(\mathrm{r}=0.42)$. Regression analysis showed that us-CRP concentration was positively associated with TC, glucose, and waist-hip ratio. These parameters explained $41 \%$ of the variability in us-CRP. Conclusion: Obese individuals present a higher concentration of us-CRP, fasting glucose, triglycerides, and VLDL-C. Excess weight is associated with us-CRP, a finding highlighting the importance of this biomarker for the detection of individuals at cardiovascular risk.

Keywords: Anthropometry. Lipoproteins. Inflammation. Nutritional status. Biomarkers.

\section{RESUMO}

Objetivo: Avaliar a correlação entre a proteína C reativa ultrasensível (PCR-us) e os marcadores clássicos de risco cardiovascular em adultos hipercolesterolêmicos em diferentes estados nutricionais. Métodos: Amostra de 46 indivíduos hipercolesterolêmicos (7 homens: 30 a 70 anos e 39 mulheres: 45 a 70 anos) com colesterol total (CT) $>240 \mathrm{mg} / \mathrm{dL}$. Realizou-se determinações antropométricas como peso, altura, circunferência da cintura (CC) e do quadril (CQ), além de medidas plasmáticas de PCR-us, CT, HDL-C, LDL-C, VLDL-C, triglicerídeos (TG), apolipoproteína AI (Apo AI), apolipoproteína B (Apo B), glicose e insulina de jejum e HOMA-IR. Realizou-se correlações de Spearman e análise de regressão linear múltipla ao nível de significância de 5\%. Resultados: Os níveis plasmáticos de TG, VLDL-C, glicose, HDL-C e PCR-us foram maiores em indivíduos com sobrepeso $(\mathrm{p}<0,05)$. A PCR-us foi positivamente correlacionada com o índice de massa corporal $(\mathrm{r}=0,32)$ e com a CQ $(\mathrm{r}=0,30)$, bem como com o CT $(r=0,33)$, Apo B $(r=0,36)$ e glicose $(r=0,42)$. A análise de regressão mostrou que a concentração de PCR-us foi positivamente associada ao CT, glicose e razão cintura-quadril. Esses parâmetros explicam a variabilidade da PCR-us em 41\%. Conclusão: Os indivíduos obesos têm maior concentração plasmática de PCR-us, glicose, TG e VLDL-C. O excesso de peso está correlacionado com a PCR-us, mostrando a importância deste biomarcador para triagem de indivíduos de risco cardiovascular.

Palavras-chave: Antropometria. Lipoproteínas. Inflamação. Estado nutricional. Biomarcadores.
Karoline de Macêdo Gonçalves Frota $^{1 *}$, Joilane Alves Pereira Freire $^{2}$, Regilda Saraiva dos Reis Moreira-Araújo'1, Valdenir Queiroz Ribeiro ${ }^{3}$, José Alfredo Gomes Arêas $^{4}$

${ }^{1}$ Department of Nutrition, Federal University of Piauí - UFPI, Teresina-PI, Brazil 2Department of Nutrition, Federal University of Piauí - UFPI, PicosPI, Brazil

${ }^{3}$ Brazilian Agricultural Research Corporation, Embrapa Meio Norte, Teresina-PI, Brazil

${ }^{4}$ Laboratory of Food Functional Properties, Department of Nutrition, School of Public Health, University of São Paulo - USP, São Paulo-SP, Brazil

*Correspondence information: Karoline de Macêdo Gonçalves Frota

Universidade Federal do Piauí UFPI - Campos Ministro Petrônio Portela, SG-13, Ininga, CEP 64049550 , Teresina-PI, Brasil E-mail: karolfrota@ufpi.edu.br

Presentation at scientific meeting: $11^{\circ}$ Congresso nacional da SBAN: Nutrição baseada em evidências. Fortaleza-CE, 2011. 


\section{INTRODUCTION}

Cardiovascular diseases are the leading cause of death in Brazil. A large number of epidemiological studies have shown a clear correlation between obesity and cardiovascular risk factors. ${ }^{1}$ This correlation becomes relevant since the prevalence of obesity has increased significantly in Brazil and in the world. ${ }^{2,3}$ Data from the 2008-2009 Brazilian Household Budget Survey (POF-IBGE, Brazil) show that about half of the male and female population is overweight, with $12.5 \%$ of obese men and $16.9 \%$ of obese women. ${ }^{2}$

Body mass index (BMI), a commonly used surrogate of overall adiposity which is strongly associated with an increased risk of cardiovascular disease, also shows a direct association with other cardiovascular risk factors such as atherosclerosis. ${ }^{4-6}$ Atherosclerosis is the main contributor to the pathogenesis of stroke and myocardial infarction. Laboratory and experimental evidence indicates that atherosclerosis, in addition to being a disease caused by lipid accumulation, also represents a chronic inflammatory process. Therefore, the quantification of ultrasensitive C-reactive protein (us-CRP), a marker of inflammation, may be a complementary method for overall cardiovascular risk assessment. ${ }^{5}$ In this respect, it has been suggested that inflammatory reactions, oxidative stress and insulin resistance represent the link between obesity and the occurrence of cardiovascular diseases in adults. ${ }^{6}$

Adipose tissue produces several adipocytokines such as interleukin-6 (IL-6), adiponectin, leptin, and tumor necrosis factor alpha (TNF- $\alpha)$. An imbalance in these substances can modify a number of factors associated with cardiovascular disease (appetite, energy balance, insulin sensitivity, blood pressure, lipid metabolism, immunity, and homeostasis). ${ }^{7}$ Activation of these factors favors the development of a low-intensity inflammatory process. This process is characterized by a mild increase in biomarkers, such as us-CRP, which can actively contribute to endothelial injury, increasing the risk of coronary artery disease. ${ }^{6,8}$

In terms of clinical application, us-CRP seems to be a better predictor of cardiovascular events than LDL-c and adds prognostic information to all levels of calculated Framingham Risk. Ultrasensitive
CRP levels $<1,1-3$ and $>3 \mathrm{mg} / \mathrm{L}$ correspond to a low, moderate and high risk of future cardiovascular events. Individuals with LDL-c $<130 \mathrm{mg} / \mathrm{dL}$ who present us-CRP $>3 \mathrm{mg} / \mathrm{L}$ are a high risk group and are often wrongly classified in clinical practice.

A strong relationship exists between anthropometric parameters, lipid profile, us-CRP and cardiovascular risk. The objective of this study was to evaluate the relationship between us-CRP and classical markers of cardiovascular risk in hypercholesterolemic adults of differing nutritional status.

\section{METHODS}

\section{SubJeCtS AND STUdY DESIGN}

A cross-sectional study was conducted on 46 hypercholesterolemic subjects (total cholesterol, TC $>240 \mathrm{mg} / \mathrm{dL}$ ). Men (30 to 70 years) and women (45-70 years) were recruited during routine visits from the cardiology, gynecology and endocrinology clinics of the Getulio Vargas Hospital and the Linnaeus Araújo Integrated Center, Teresina-PI.

Excluded were subjects who used cholesterollowering statins or other lipid-lowering drugs during 8 weeks prior to the study; women receiving hormone replacement therapy during 6 months prior to the beginning of the study who were not postmenopausal; subjects with significant signs of cardiovascular disease and renal, hepatic, gastrointestinal and endocrine conditions, including diabetes mellitus; subjects with a family history of hypercholesterolemia and uncontrolled hypertension; subjects with triglyceride concentrations higher than $400 \mathrm{mg} / \mathrm{dL}$.

The participants received detailed information about the objectives and methodology of the study and signed the informed consent form. The protocol was approved by the Ethics Committees of the Federal University of Piauí and of the School of Medicine, University of São Paulo.

\section{AntHRopometrics eVALUATION}

The anthropometric data were obtained as described by Gordon et al. (1988)..$^{10}$ The subjects were weighed on a Fillizola ${ }^{\circledR}$ platform scale (capacity of 150kg; Sao Paulo, Brazil) to the nearest $100 \mathrm{~g}$. Height was measured using a SECA ${ }^{\circledR}$ stadiometer (Hamburg, Germany) to the nearest $0.1 \mathrm{~cm}$. The BMI [BMI $=$ weight $(\mathrm{kg}) /$ height $\left.^{2}(\mathrm{~m})\right]$ was calculated 
and nutritional status was assessed according to WHO criteria (1998). ${ }^{11}$ Waist circumference (WC) ${ }^{12}$ and hip circumference $(\mathrm{HC})^{12}$ were measured with a tape measure (Stanley, model 34 103, New Britain, CT, USA) to the nearest $0.1 \mathrm{~cm}$. The waist-hip ratio (WHR) was calculated by dividing WC by HC.

The participants were divided into three groups based on BMI classification: healthy weight (BMI 18.5 to $24.9 \mathrm{~kg} / \mathrm{m}^{2}$ ), overweight (BMI 25.0 to $\left.29.9 \mathrm{~kg} / \mathrm{m}^{2}\right)$, and obese $\left(\mathrm{BMI} \geq 30 \mathrm{~kg} / \mathrm{m}^{2}\right)$.

\section{Biochemical ANALYSES}

Immediately after blood sample collection for the determination of glucose, insulin and lipid profile, the material was centrifuged at $1500 \mathrm{rpm}$ for $10 \mathrm{~min}\left(\right.$ Tomy $^{\circledR}$ centrifuge, model IC-15AN, Tominaga Works Ltd., Tokyo, Japan) and then stored in a refrigerator at $0^{\circ} \mathrm{C}$ for a period of 24-48h until the time of the biochemical tests.

Serum us-CRP was determined by a chemiluminescence assay (Immulite ${ }^{\circledR}$, DPC, Los Angeles, CA, USA). Serum TC and triglyceride concentrations were measured by enzymatic colorimetric methods using kits purchased from Labtest $^{\circledR}$ (Belo Horizonte, Brazil). HDL-c was analyzed by enzymatic methods using commercial kits (Roche Diagnostics ${ }^{\circledR}$, Somerville, NJ, USA). LDL-c was calculated using the equation of Friedewald et al. (1972)..$^{13}$ Apo-AI and Apo-B were measured by automated standardized immunoassays using kits obtained from Roche Diagnostics ${ }^{\circledR}$.

Glucose was determined by enzymatic colorimetric methods using kits purchased from Labtest $^{\circledR}$ (Belo Horizonte, Brazil). Insulin was assayed in serum by a chemiluminescence method using the Immulite-2000 system (Immulite ${ }^{\circledR}$, DPC, Los Angeles, CA, USA). The homeostasis model assessment (HOMA) method was used to determine insulin resistance as follows ${ }^{14}$ : HOMA$\mathrm{IR}=$ fasting glucose $(\mathrm{mmol} / \mathrm{l}) \times$ fasting insulin $(\mathrm{mU} / \mathrm{ml}) / 22.5$.

\section{Statistical analysis}

Analysis of variance, a simple Spearman's correlation test, comparison of means and stepwise multiple regression analysis were used to determine the dependent or independent variables that best explained the variation in us-CRP according to the method proposed by Garcia et al. (2002). ${ }^{15}$ Means were adjusted by the least squares method using the LSMEANS procedure of the SAS program (SAS Institute, 2000) ${ }^{16}$ and were compared by the $t$-test, adopting a level of significance of $5 \%$.

\section{RESULTS}

Forty-six hypercholesterolemic subjects met the inclusion criteria; of these, 14 were healthy weight, 20 were overweight, and 12 were obese. There were 39 women (85\%) and 7 men (15\%).

Table 1 shows the anthropometric characteristics of the patients (BMI, WC, HC, and WHR). There was a significant difference in all variables between BMI groups (BMI: $\mathrm{p}<0.001$, WC: $\mathrm{p}<0.001$, HC:p<0.001, and WHR: $\mathrm{p}=0.0219)$.

The three groups were homogenous in terms of age, height, LDL-c, TC, apo AI, apo B, fasting insulin, and HOMA-IR. However, fasting insulin $(p=0.0873)$ and HOMA-IR $(p=0.0890)$ tended to increase with worsening of nutritional status. Overweight and obese subjects presented higher HDL-c, triglycerides, VLDL-c, and glucose concentrations. The levels of us-CRP were higher in the obese group than in healthy weight subjects $(\mathrm{p}=0.0487)$ (Table 1).

Higher glucose levels were observed in the groups with higher BMI (overweight $=99.3 \mathrm{mg} / \mathrm{dL}$ and obese $=101.5 \mathrm{mg} / \mathrm{dL}, \mathrm{p}<0.0001)$, accompanying the highest levels of us-CRP (overweight $=1.26 \mathrm{mg} /$ $\mathrm{dL}$ and obese $=1.38 \mathrm{mg} / \mathrm{dL}, \mathrm{p}=0.0487$ ) (Table 1).

Analysis of the correlation between us-CRP and anthropometric variables showed a positive correlation with BMI and HC ( $\mathrm{p}<0.05)$ (Figure 1). In addition, $\mathrm{TC}(\mathrm{r}=0.326$ and $\mathrm{p}=0.026)$, apo $\mathrm{B}$ $(\mathrm{r}=0.362$ and $\mathrm{p}=0.013)$ and glucose $(\mathrm{r}=0.423$ and $\mathrm{p}=0.002$ ) were positively correlated with us-CRP concentration (Figure 2). These results were supported by multiple linear regression analysis, which showed that TC, fasting glucose and WHR positively influenced the concentration of usCRP (Table 2). These parameters explained $41 \%$ of the variability in us-CRP.

\section{DISCUSSION}

Overweight is known to be a risk factor for atherosclerosis and arterial inflammation and plays an important role in the onset and progression of 
Table 1. Anthropometric and clinical characteristics of the groups according to nutritional status.

\begin{tabular}{|c|c|c|c|}
\hline & $\begin{array}{l}\text { Healthy weight } \\
\qquad(\mathrm{n}=14)\end{array}$ & $\begin{array}{l}\text { Overweight } \\
\qquad(\mathrm{n}=20)\end{array}$ & $\begin{array}{c}\text { Obese } \\
(\mathrm{n}=12)\end{array}$ \\
\hline Age (years) & $60.28 \pm 0.17^{\mathrm{a}}$ & $54.47 \pm 0.14^{\mathrm{a}}$ & $54.50 \pm 0.20^{\mathrm{a}}$ \\
\hline Height (m) & $1.53 \pm 0.01^{\mathrm{a}}$ & $1.55 \pm 0.01^{\mathrm{a}}$ & $1.56 \pm 0.02^{\mathrm{a}}$ \\
\hline BMI $\left(\mathrm{kg} / \mathrm{m}^{2}\right)$ & $23.55 \pm 0.34^{\mathrm{c}}$ & $27.52 \pm 0.27^{\mathrm{b}}$ & $32.90 \pm 0.40^{\mathrm{a}}$ \\
\hline $\mathrm{WC}(\mathrm{cm})$ & $79.95 \pm 1.37^{c}$ & $89.61 \pm 1.12^{b}$ & $98.16 \pm 1.55^{\mathrm{a}}$ \\
\hline $\mathrm{HC}(\mathrm{cm})$ & $98.58 \pm 0.59^{c}$ & $103.45 \pm 0.48^{\mathrm{b}}$ & $112.85 \pm 0.67^{\mathrm{a}}$ \\
\hline WHR & $0.82 \pm 0.01^{\mathrm{b}}$ & $0.86 \pm 0.01^{\mathrm{a}}$ & $0.88 \pm 0.01^{\mathrm{a}}$ \\
\hline Total cholesterol (mg/dL) & $262.76 \pm 4.95^{\mathrm{a}}$ & $268.73 \pm 4.04^{\mathrm{a}}$ & $268.27 \pm 5.59^{a}$ \\
\hline HDL-c (mg/dL) & $49.27 \pm 1.13^{\mathrm{a}}$ & $56.02 \pm 0.92^{\mathrm{b}}$ & $53.40 \pm 1.28^{\mathrm{b}}$ \\
\hline LDL-c (mg/dL) & $178.09 \pm 3.80^{\mathrm{a}}$ & $181.28 \pm 3.10^{\mathrm{a}}$ & $185.68 \pm 4.29^{\mathrm{a}}$ \\
\hline Triglycerides (mg/dL) & $135.66 \pm 9.48^{\mathrm{a}}$ & $145.20 \pm 7.74^{\mathrm{ab}}$ & $167.36 \pm 10.70^{\mathrm{b}}$ \\
\hline VLDL-c (mg/dL) & $27.13 \pm 1.90^{\mathrm{a}}$ & $29.04 \pm 1.55^{\mathrm{ab}}$ & $33.47 \pm 2.14^{\mathrm{b}}$ \\
\hline Apolipoprotein AI (mg/dL) & $157,00 \pm 3,63^{\mathrm{a}}$ & $151,25 \pm 2,97^{\mathrm{a}}$ & $153,58 \pm 4,10^{\mathrm{a}}$ \\
\hline Apolipoprotein B (mg/dL) & $130.39 \pm 3.19^{\mathrm{a}}$ & $126.86 \pm 2.61^{\mathrm{a}}$ & $129.38 \pm 3.60^{\mathrm{a}}$ \\
\hline Fasting glucose (mg/dL) & $92.41 \pm 1.64^{\mathrm{a}}$ & $99.31 \pm 1.33^{\mathrm{b}}$ & $101.55 \pm 1.85^{\mathrm{b}}$ \\
\hline Fasting insulin $(\mu \mathrm{IU} / \mathrm{mL})$ & $2.36 \pm 0.30^{\mathrm{a}}$ & $2.76 \pm 2.24^{\mathrm{a}}$ & $3.37 \pm 0.33^{\mathrm{a}}$ \\
\hline HOMA-IR & $0.56 \pm 0.06^{\mathrm{a}}$ & $0.67 \pm 0.05^{\mathrm{a}}$ & $0.78 \pm 0.07^{a}$ \\
\hline us-CRP (mg/L) & $0.98 \pm 0.11^{\mathrm{a}}$ & $1.26 \pm 0.09^{\mathrm{ab}}$ & $1.38 \pm 0.12^{\mathrm{b}}$ \\
\hline
\end{tabular}

Mean \pm standard error. Values in the same line followed by the same superscript letter do not differ by ANOVA (5\% probability); BMI, body mass index; WC, waist circumferences; HC, hip circumferences; WHR, waist-hip ratio; HOMA-IR, homeostasis model assessment of insulin resistance; us-CRP, ultrasensitive C-reactive protein.
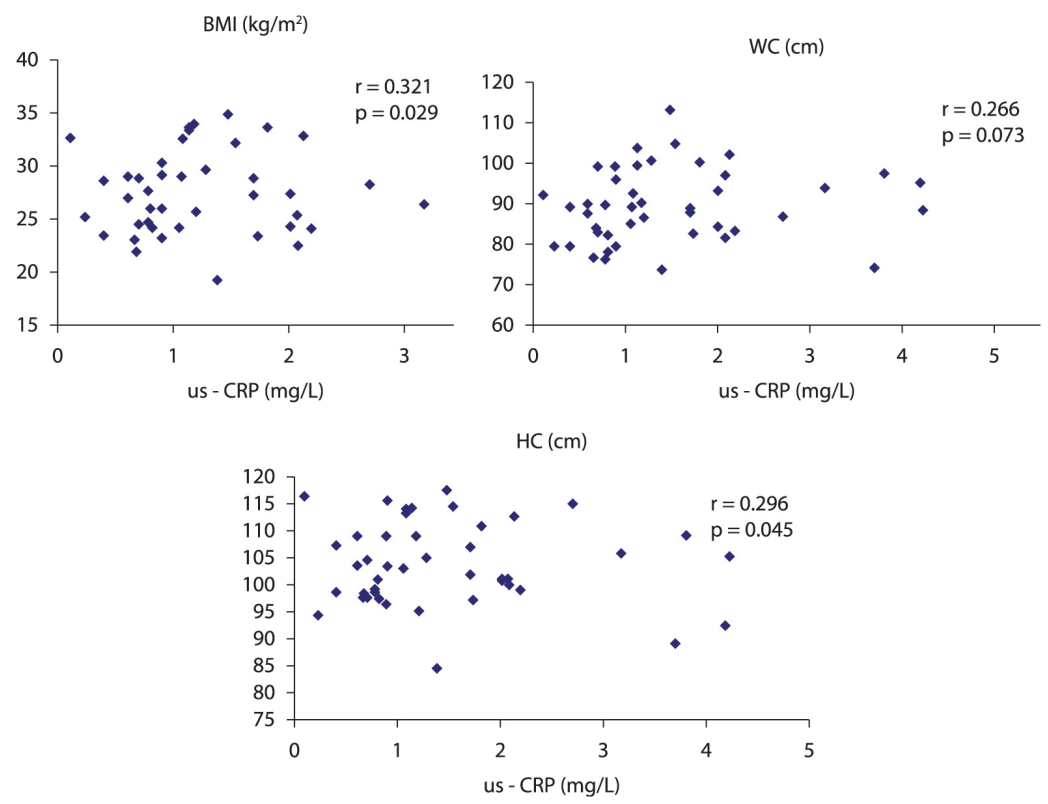

Figure 1. Correlations between ultrasensitive C-reactive protein (us-CRP) and body mass index (BMI), waist circumference (WC), and hip circumference (HC). 

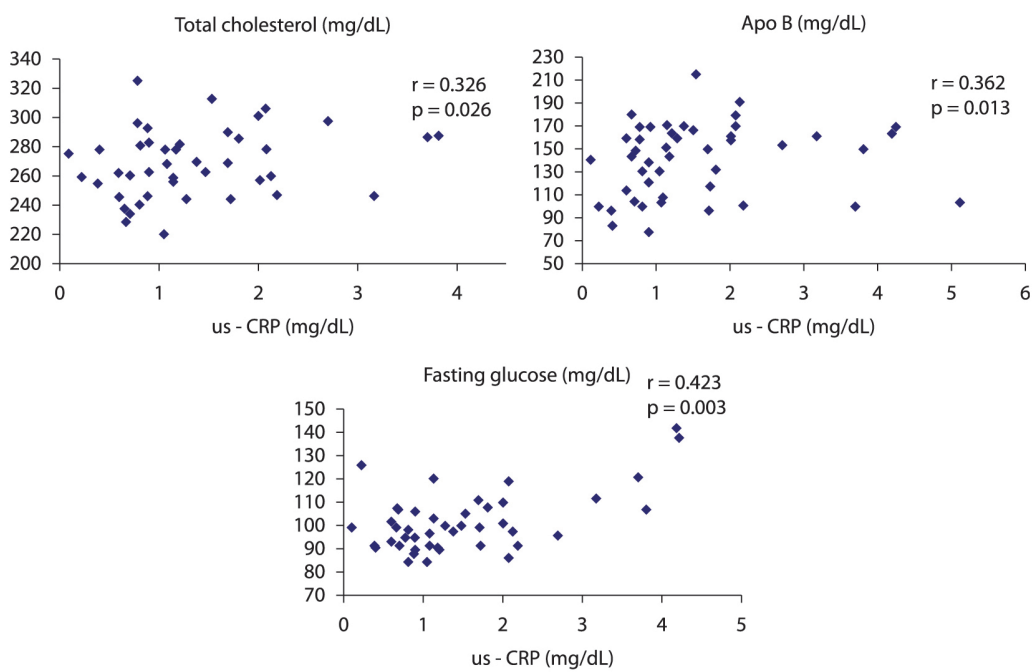

Figure 2. Correlations between ultrasensitive C-reactive protein (us-CRP) and total cholesterol, fasting glucose and apolipoprotein B (Apo B).

Table 2. Multiple linear regression analysis using ultrasensitive C-reactive protein as the dependent variable (TeresinaPI, Brazil, 2010-2011).

\begin{tabular}{|l|c|c|c|}
\hline \multicolumn{1}{|c|}{ Independent variable } & $\boldsymbol{\beta}$ Coefficient & Standard error & P \\
\hline Total cholesterol $(\mathrm{mg} / \mathrm{dL})$ & 0.009 & 0.003 & 0.004 \\
\hline Fasting glucose $(\mathrm{mg} / \mathrm{dL})$ & 0.021 & 0.009 & 0.035 \\
\hline Waist-hip ratio & 2.686 & 1.131 & 0.022 \\
\hline HOMA-IR & -0.393 & 0.221 & 0.082 \\
\hline
\end{tabular}

$\mathrm{R}^{2}=0.4109$, adjusted $\mathrm{R}^{2}=0.3534$; The final prediction model was obtained by stepwise multiple regression analysis. The following variables were evaluated as independent variables in the regression model: total cholesterol, triglycerides, fasting glucose, weight, BMI, waist circumference, hip circumference, and waist-hip ratio. Only variables with a p value $<0.05$ were included in the final model. $\beta$ indicates the regression coefficient.

atherosclerosis. In the present study, obese patients showed higher us-CRP concentrations $(1.38 \mathrm{mg} / \mathrm{L})$ than healthy weight patients $(0.98 \mathrm{mg} / \mathrm{L})$. The same trend has been reported in a study on adults, in which subjects with higher CRP levels $(>1.2 \mathrm{mg} / \mathrm{L})$ had an average BMI indicating overweight, whereas those with lower CRP levels $(<1.2 \mathrm{mg} / \mathrm{dL})$ had an average $\mathrm{BMI}$ indicating healthy weight. ${ }^{17}$

Fasting glucose levels were higher in the groups with higher BMI. The same was observed for usCRP levels (Table 1). Ultrasensitive CRP is an acute phase protein and a sensitive marker of subclinical inflammation. ${ }^{18}$ High us-CRP levels are known to predict the development of type 2 diabetes and cardiovascular disease in healthy populations. ${ }^{19,20}$ Experimental studies have shown that 25-30\% of circulating IL-6 is produced by subcutaneous adipose tissue. ${ }^{21}$ IL- 6 is the main proinflammatory cytokine and a primary determinant of hepatic production of us-CRP, a fact that may explain the higher levels of usCRP and glucose in the group of subjects with higher BMI, as well as the positive correlation between us-CRP $\mathrm{x}$ glucose and usCRP x BMI (Figures 1 and 2).

Mean us-CRP was $1.19 \mathrm{mg} / \mathrm{L}$ in this study, a value similar to the $1.16 \mathrm{mg} / \mathrm{L}$ observed in the American population without known cardiovascular disease. ${ }^{5}$ The cutoff points of us-CRP for the classification of future cardiovascular disease risk, established for apparently healthy American men and women, are 0.1 to $0.7 \mathrm{mg} / \mathrm{L}$ (low risk), 0.7 to $1.1 \mathrm{mg} / \mathrm{L}$ (mild risk), 1.2 to $1.9 \mathrm{mg} / \mathrm{L}$ (moderate 
risk), 2 to $3.8 \mathrm{mg} / \mathrm{L}$ (high risk), and 3.8 to $15 \mathrm{mg} / \mathrm{L}$ (highest risk). ${ }^{5}$ According to these cutoff values, subjects of the present study with a healthy weight have a mild risk, while those with excess weight (overweight and obese) have a moderate risk of future cardiovascular disease.

Studies have shown that the concentration of us-CRP in adults is positively associated with $\mathrm{BMI}$ and WC. ${ }^{22,23}$ In addition, it is known that us-CRP, in addition to being a good predictor of cardiovascular risk, is a potential mediator of inflammation in atherosclerotic lesions. In the present study, the correlation between us-CRP and WC was not statistically significant, but there was a tendency towards a significant positive correlation $(\mathrm{r}=0.266 ; \mathrm{p}=0.073)$.

Analysis of the correlation between us-CRP and biochemical data showed a positive correlation with fasting glucose, apo B and TC. The positive correlation between glucose and us-CRP corroborates the findings of previous studies demonstrating an association between us-CRP and increased risk of diabetes and cardiovascular disease. ${ }^{24-26}$ The West of Scotland Coronary Prevention Study showed that non-diabetic men with us-CRP $>0.42 \mathrm{mg} /$ $\mathrm{dL}$ had a 3-fold increased risk of developing diabetes within 5 years. ${ }^{27}$ A study conducted on 510 Chinese patients diagnosed with type 2 diabetes demonstrated a significant correlation between usCRP and HOMA-IR, BMI and WC. ${ }^{28}$ Nakanishi et al $(2005)^{29}$ reported a strong correlation between fasting glucose and us-CRP in Japanese women compared to Japanese men.

Although BMI is probably the most important clinically recognized risk factor for type 2 diabetes, obesity is neither sufficient nor decisive for the incidence of diabetes, since a follow-up study showed that about $20 \%$ of adult women who developed diabetes were lean, defined as a $\mathrm{BMI}<25 \mathrm{~kg} / \mathrm{m}$. 2,30 This observation is supported by the findings of Sabanayagam et al. (2011) $)^{25}$ who observed an association between us-CRP and prediabetes among participants without diabetes, irrespective of their nutritional status (BMI).

A longitudinal study including initially non-diabetic individuals has shown that fasting hyperinsulinemia is predictive of future cardiovascular events. ${ }^{31}$ This finding might be explained by the well-described relationship between subclinical inflammation and the development of atherosclerosis. ${ }^{1,4,8,32}$ The effect of elevated us-CRP and coinciding systemic inflammation on hyperinsulinemia could be partially responsible for the previously reported associations between increased insulin levels and cardiovascular risk. ${ }^{18}$ In the present study, no significant correlation was observed between us-CRP and insulin. However, there was a clear tendency towards higher mean insulin levels in the group of obese individuals (healthy weight $=2.36 \mu \mathrm{IU} / \mathrm{mL}$ vs obese $=3.37 \mu \mathrm{IU} / \mathrm{mL}$, $\mathrm{p}=0.087$ ).

Multiple linear regression analysis showed that us-CRP concentration was positively associated with TC, fasting glucose and WHR. A collaborative cross-sectional study involving 101,510 subjects also found an association of us-CRP with TC and glucose levels after multiple regression analysis. ${ }^{33}$

A study limitation was the sample size used which weakened the correlations, however it was enough to show the existence of a significant correlation between overweight / obesity and subclinical inflammation in hypercholesterolemic individuals. Therefore, the weight loss can be strategy for the control of other cardiovascular risk factors such as us-CRP, total cholesterol, glucose and atherogenic apolipoprotein (apo B).

\section{CONCLUSIONS}

In summary, this study demonstrated a higher concentration of us-CRP in obese individuals compared to healthy weight subjects. In addition, fasting glucose, TC, apo B protein and overweight were associated with the level of usCRP. This finding highlights the importance of us-CRP for cardiovascular disease risk screening.

\section{ACKNOWLEDGEMENTS}

The authors are grateful to FAPESP and CNPq (Grant 480344/2008-6) for financial support, and to the Getulio Vargas Hospital and the Linnaeus Araújo Integrated Center, Teresina-PI, for permitting this study at their institutions. 


\section{REFERENCES}

1. Fontes JD, Yamamoto JF, Larson MG, Wang N, Dallmeier $\mathrm{D}$, Rienstra $\mathrm{M}$, et al. Clinical correlates of change in inflammatory biomarkers: The Framingham Heart Study. Atherosclerosis. 2013;228(1):217-23. http:/ / dx.doi.org/10.1016/j.atherosclerosis.2013.01.019. PMid:23489346

2. Instituto Brasileiro de Geografia e Estatística - IBGE. POF 2008 2009: antropometria e estado nutricional de crianças, adolescentes e adultos no Brasil. Rio de Janeiro; 2010 [cited 2014 Feb 10]. Available from: http://www.ibge.gov.br/home/presidencia/noticias/ noticia_visualiza.php?id_noticia=1699\&id_pagina=1.

3. World Health Organization - WHO. Cardiovascular disease: prevention and control. Global Strategy on Diet, Physical Activity and Health [cited 2007 Feb 1]. Available from: http://www.who.int/dietphysicalativity/ publications/facts/cvd/en/.

4. Yusuf S, Anand S. Body-mass index, abdominal adiposity, and cardiovascular risk. Lancet. 2011;378(9787):226-7. http://dx.doi.org/10.1016/S0140-6736(11)61120-3. PMid:21763930

5. Gupta S, Gupta VK, Gupta R, Arora S, Gupta V. Relationship of high-sensitive $\mathrm{C}$-reactive protein with cardiovascular risk factors, clinical presentation and angiographic profile in patients with acute coronary syndrome: an Indian perspective. Indian Heart J. 2013;65(3):359-65. http://dx.doi.org/10.1016/j. ihj.2013.04.035. PMid:23809399

6. Soriano-Guillén L, Hernández-García B, Pita J, Domínguez-Garrido N, Del Río-Camacho G, Rovira A. High-sensitivity C-reactive protein is a good marker of cardiovascular risk in obese children and adolescents. Eur J Endocrinol. 2008;159(1):R1-4. http://dx.doi. org/10.1530/EJE-08-0212. PMid:18450770

7. Wang P, Mariman E, Renes J, Keijer J. The secretory function of adipocytes in the physiology of white adipose tissue. J Cell Physiol. 2008;216(1):3-13. http:/ / dx.doi.org/10.1002/jcp.21386. PMid:18264975

8. Xu H. Obesity and metabolic inflammation. Drug Discov Today Dis Mech. 2013;10(1-2):1-8. http://dx.doi. org/10.1016/j.ddmec.2013.03.006. PMid:24003334

9. Ridker PM. Clinical application of C-reactive protein for cardiovascular disease detection and prevention. Circulation. 2003;107(3):363-9. http://dx.doi.org/10.1161/01. CIR.0000053730.47739.3C. PMid:12551853

10. Gordon CC, Cameron W, Roche AF. Stature, recumbent length, and weight. In: Lohman TG, Roche AF, Martorell
R. Anthropometric standardization reference manual. Illinois: Human Kinetics Publishers; 1988. p. 3-8.

11. World Health Organization - WHO. Obesity: preventing and managing the global epidemic. Geneva; 1998. Report of a WHO Consultation on Obesity.

12. World Health Organization - WHO. Expert Committee. Physical status: the use and interpretation of anthropometry. Geneva; 1995.

13. Friedewald WT, Levy RI, Fredrickson DS. Estimation of the concentration of low-density lipoprotein cholesterol in plasma, without use of the preparative ultracentrifuge. Clin Chem. 1972;18(6):499-502. PMid:4337382.

14. Matthews DR, Hosker JP, Rudenski AS, Naylor BA, Treacher DF, Turner RC. Homeostasis model assessment: insulin resistance and beta-cell function from fasting plasma glucose and insulin concentrations in man. Diabetologia. 1985;28(7):412-9. http:/ /dx.doi. org/10.1007/BF00280883. PMid:3899825

15. Garcia AAF, Barbin D, Piedade SMS. LCE 602: estatística experimental (aulas práticas). Piracicaba: ESALQ; 2002. 63 p.

16. SAS Institute. SAS/STAT: user's guide, version 8.1. Cary; 2000. 943 p. (v. 1).

17. Carvalho Vidigal F, Paez de Lima Rosado LE, Paixão Rosado G, de Cassia Lanes Ribeiro R, do Carmo Castro Franceschini S, Priore SE, et al. Predictive ability of the anthropometric and body composition indicators for detecting changes in inflammatory biomarkers. Nutr Hosp. 2013;28(5):1639-45. PMid:24160228.

18. Pradhan AD, Cook NR, Buring JE, Manson JE, Ridker PM. C-reactive protein is independently associated with fasting insulin in nondiabetic women. Arterioscler Thromb Vasc Biol. 2003;23(4):650-5. http:/ / dx.doi.org/10.1161/01.ATV.0000065636.15310.9C. PMid:12692007

19. Thorand B, Löwel H, Schneider A, Kolb H, Meisinger C, Fröhlich M, et al. C-reactive protein as a predictor for incident diabetes mellitus among middle-aged men: results from the MONICA Augsburg cohort study, 1984-1998. Arch Intern Med. 2003;163(1):93-9. http:/ / dx.doi.org/10.1001/archinte.163.1.93. PMid:12523922

20. Ridker PM, Hennekens CH, Buring JE, Rifai N. $\mathrm{C}$-reactive protein and other markers of inflammation in the prediction of cardiovascular disease in women. N Engl J Med. 2000;342(12):836-43. http://dx.doi. org/10.1056/NEJM200003233421202. PMid:10733371 
21. Mohamed-Ali V, Goodrick S, Rawesh A, Katz DR, Miles JM, Yudkin JS, et al. Subcutaneous adipose tissue releases interleukin-6, but not tumor necrosis factor- $\alpha$, in vivo. J Clin Endocrinol Metab. 1997;82(12):4196200. PMid:9398739.

22. Snodgrass JJ, Leonard WR, Tarskaia LA, McDade TW, Sorensen MV, Alekseev VP, et al. Anthropometric correlates of C-reactive protein among indigenous Siberians. J Physiol Anthropol. 2007;26(2):241-6. http:/ / dx.doi.org/10.2114/jpa2.26.241. PMid:17435372

23. Ganguli D, Das N, Saha I, Sanapala KR, Chaudhuri $\mathrm{D}$, Ghosh S, et al. Association between inflammatory markers and cardiovascular risk factors in women from Kolkata, W.B, India. Arq Bras Cardiol. 2011;96(1):38-46. http://dx.doi.org/10.1590/S0066-782X2010005000165. PMid:21180893

24. Hu G, Jousilahti P, Tuomilehto J, Antikainen R, Sundvall J, Salomaa V. Association of serum C-reactive protein level with sex-specific type 2 diabetes risk: a prospective finnish study. J Clin Endocrinol Metab. 2009;94(6):2099-105. http://dx.doi.org/10.1210/ jc.2008-2260. PMid:19318443

25. Sabanayagam C, Shankar A, Lim SC, Lee J, Tai ES, Wong TY. Serum C-reactive protein level and prediabetes in two Asian populations. Diabetologia. 2011;54(4):76775. http://dx.doi.org/10.1007/s00125-011-2052-5. PMid:21267537

26. Buckley DI, Fu R, Freeman M, Rogers K, Helfand M. $\mathrm{C}$-reactive protein as a risk factor for coronary heart disease: a systematic review and meta-analyses for the U.S. Preventive Services Task Force. Ann Intern Med. 2009;151(7):483-95. http://dx.doi.org/10.7326/00034819-151-7-200910060-00009. PMid:19805771

27. Freeman DJ, Norrie J, Caslake MJ, Gaw A, Ford I, Lowe GD, et al, and the West of Scotland Coronary Prevention Study. C-reactive protein is an independent predictor of risk for the development of diabetes in the
West of Scotland Coronary Prevention Study. Diabetes. 2002;51(5):1596-600. http://dx.doi.org/10.2337/ diabetes.51.5.1596. PMid:11978661

28. Lu B, Yang Y, Yang Z, Feng X, Wang X, Zhang $Z$, et al. Insulin resistance in Chinese patients with type 2 diabetes is associated with $\mathrm{C}$-reactive protein independent of abdominal obesity. Cardiovasc Diabetol. 2010;9:92. http://dx.doi.org/10.1186/1475-2840-9-92. PMid:21167068

29. Nakanishi N, Shiraishi T, Wada M. Association between fasting glucose and C-reactive protein in a Japanese population: the Minoh study. Diabetes Res Clin Pract. 2005;69(1):88-98. http://dx.doi.org/10.1016/j. diabres.2004.11.009. PMid:15955391

30. Carey VJ, Walters EE, Colditz GA, Solomon CG, Willet WC, Rosner BA, et al. Body fat distribution and risk of non-insulin-dependent diabetes mellitus in women. The Nurses' Health Study. Am J Epidemiol. 1997;145(7):614-9. http://dx.doi.org/10.1093/ oxfordjournals.aje.a009158. PMid:9098178

31. Papakonstantinou E, Lambadiari V, Dimitriadis G, Zampelas A. Metabolic syndrome and cardiometabolic risk factors. Curr Vasc Pharmacol. 2013;11(6):858-79. http://dx.doi.org/10.2174/15701611113116660176. PMid:24484465

32. Schnabel RB, Yin X, Larson MG, Yamamoto JF, Fontes JD, Kathiresan S, et al. Multiple inflammatory biomarkers in relation to cardiovascular events and mortality in the community. Arterioscler Thromb Vasc Biol. 2013;33(7):1728-33. http://dx.doi.org/10.1161/ ATVBAHA.112.301174. PMid:23640499

33. Wu SL, Li JF, Li Y, Jin C, Wang LY, Ruan CY, et al. [The distribution and influential factors of serum high sensitivity $C$-reactive protein in general population]. Zhonghua Nei Ke Za Zhi. 2010;49(12):1010-4. PMid:21211357. 


\section{ADDITIONAL INFORMATION}

Frota KMG: Dra., UFPI.

Freire JAP: MSc., UFPI.

Moreira-Araújo RSR: Dra., UFPI.

Ribeiro VQ: MSc., EMBRAPA Meio Norte.

Arêas JAG: Dr., USP

Place where the work was developed: Gynecology and endocrinology clinics, Getúlio Vargas Hospital, Teresina-Piauí, Brazil. Cardiology clinics, Linnaeus Araújo Integrated Center, Teresina, PI, Brazil.

Work based on thesis: This study is part of a thesis entitled "Effect of cowpea protein (Vigna unguiculata L. Walp) on markers of cardiovascular disease risk in hypercholesterolemic patients", defended by Karoline de Macêdo Gonçalves Frota in 2011 in partial fulfillment of the requirements for the Doctoral degree in the program of Public Health Nutrition of the University of São Paulo. Department of Nutrition, School of Public Health, University of São Paulo, São Paulo-SP, Brazil.

Financing source: Support: CNPq (Grant 480344/2008-6); FAPESP fellowship: Grant 2007/05720-0.

Conflicts of interest: The authors declare no conflict of interest that might have interfered with the impartiality of this work.

Research Ethics Committee approval statement: The protocol was approved by the Ethics Committees of the Federal University of Piauí (CAAE 0206.0045.000-09) and of the School of Medicine, University of São Paulo (Protocol No. 1037/07).

Received: Aug. 18, 2014

Accepted: Nov. 22, 2014 